American Journal of Applied Sciences 6 (8): 1448-1452, 2009

ISSN 1546-9239

(C) 2009 Science Publications

\title{
Cross Reactivity between Dromedary Whey Proteins and IgG Anti Bovine $\alpha$-Lactalbumin and Anti Bovine $\beta$-Lactoglobulin
}

\author{
N. Youcef, D. Saidi, F. Mezemaze, K.E. El-Mecherfi, H. Kaddouri, \\ H. Negaoui, A. Chekroun and O. Kheroua \\ Laboratory of Physiology of Nutrition, Department of Biology, \\ Faculty of Science, University of Oran, Algeria
}

\begin{abstract}
Problem statement: Our aim was to enhance the data on antigenic properties of dromedary whey proteins. Approach: The identification of the whey proteins was carried by SDS-page and Reversed phase high performance liquid chromatography (RP-HPLC). The cross-reactivity of dromedary whey proteins with $\operatorname{IgG}$ anti bovine $\beta$-lactoglobulin and anti bovine $\alpha$-lactalbumin, obtained by immunisation of Balb/c mice, was carried out by ELISA. Results: The SDS-page showed the presence of band corresponding to $\alpha$-lactalbumin and albumin serum; this was confirmed by the chromatogram obtained by RP-HPLC, where we detected a pick corresponding to $\alpha$-lactalbumin. There was a cross reaction of dromedary whey proteins with IgG anti bovin $\alpha$-lactalbumin but it was very weak with IgG anti boin $\beta$-lactoglobulin. Conclusion: We detected a cross reactivity between dromedary whey proteins and IgG anti bovin $\alpha$-lactalbumin.
\end{abstract}

Key words: Cross-reactivity, dromedary milk, whey proteins, $\beta$-lactoglobulin, $\alpha$-lactalbumin, IgG

\section{INTRODUCTION}

Generally speaking, homology between milk proteins of different animal species can be the cause of cross reactivity. That homology corresponds to an immunochemical properties and three-dimensional conformation similitude between allergens of species taxonomically near or distant ${ }^{[1]}$. Consequently, cross reactions occur when two different milk proteins can bind the same immunoglobulins (Ig). Thus, there is a risk of cross reactivity between cow's milk and goat's milk $^{[2-4]}$ and between mare's milk and ewe's milk ${ }^{[5-9]}$. The dromedary remains the species taxonomically farthest away from the cow and for which there is little data on the antigenic properties of its milk proteins. That is why, in the present study, we are interested in the interaction between the whey proteins of dromedary milk and the antibodies directed against bovine $\beta$ lactoglobulin and bovine $\alpha$-lactalbumin.

\section{MATERIALS AND METHODS}

Milk samples of dromedary and cow: We used dromedary (Cameleus dromedarius) milk collected from a farm located in El Abadlaa (South of Algeria) and cow milk collected from a farm located in Sidi
Marouf (North of Algeria). The collected milk samples were pooled, kept and transported to the laboratory.

The milk samples were skimmed by centrifugation at $610 \times \mathrm{g}$ and $10^{\circ} \mathrm{C}$ for $15 \mathrm{~min}$. The acidification of dromedary milk was achieved with $\mathrm{HCl} 0.1 \mathrm{~N}$, to obtain $\mathrm{pH}=4.4$ (isoelectric $\mathrm{pH}$ of caseins) and for cow's milk until obtaining $\mathrm{pH}=4.6$ (isoelectric $\mathrm{pH}$ of caseins). After centrifugation at $610 \times \mathrm{g}$ and $10^{\circ} \mathrm{C}$ for $15 \mathrm{~min}$, the precipitate obtained represented caseins and the supernatant the whey protein.

SDS-page: Sodium dodecyl sulfate gel electrophoresis (SDS-PAGE) of milk samples (whey proteins and caseins of dromedary milk and whey proteins of cow's milk) was performed under denaturing conditions as previously described $^{[10]}$.

Proteins were separated in polyacrylamide gel (12.5\%) and stained with Coomassie Blue R250. All materials and instruments were purchased from BioRad.

Reversed phase high performance liquid chromatography (RP-HPLC): Samples of whey dromedary and purified bovine proteins: $\beta$ lactoglobulin (Sigma), $\alpha$-lactalbumin (Sigma), bovine serum albumin (Sigma) were separated by RP-HPLC

Corresponding Author: O. Kheroua, Laboratory of Physiology of Nutrition, Department of Biology, Faculty of Science, University of Oran, Algeria Tel: +21341 513025 Fax: +21341581925 
(Jasco, PU980-PU970), analytical reversed-phase C18 column (Shodex Asahipak ODP-40 4E, $4 \mu$, $4.6 \times 250 \mathrm{~mm}$; N-71083 Japan). Solvent A was $0.11 \%$ (v/v) TFA in ultra pure water, solvent B was $0.1 \%$ (v/v) TFA in acetonitrile. After injection of $20 \mu \mathrm{L}$ whey proteins filtrate, elution was performed by a $5 \mathrm{~min}$ hold with 0 solvent $\mathrm{B}$, a linear gradient from $0-30 \%$ solvent $\mathrm{B}$ over $5 \mathrm{~min}$, followed by a linear gradient from 30$70 \% \mathrm{~B}$ over $40 \mathrm{~min}$.

Preparation of antibodies, anti bovine $\beta$ lactoglobulin and anti bovine $\alpha$-lactalbumin immunisation of mice: We used 30 female mice Balb/c between 6 and 8 weeks old and weighing between 20 and $25 \mathrm{~g}(22.50 \pm 0.27 \mathrm{~g})$. The mice were sensitized by parenteral way and were distributed in two groups: one sensitized with the $\beta$-Lg (Sigma, L0130 , USA) $(n=12)$, the other one sensitized with $\alpha$ La (Sigma, L-5385, USA) $(n=12)$ and a control group (not sensitized) $(n=12)$. The sensitization of the mice was done by intraperitoneally injection of $100 \mu \mathrm{L}$ of PBS pH 7.4 solution containing $10 \mu \mathrm{g}$ of cow's milk proteins $(\beta-\mathrm{Lg}$ or $\alpha$-La) mixed with $2 \mathrm{mg}$ of aluminum hydroxide $\left[\mathrm{Al}(\mathrm{OH})_{3}\right]$. The injection was carried on day 0 (1st day of sensitizing). Other injections were done between the 14th-21st and on the 28th day. The mice were sacrificed on day 35 .

IgG titers measured by ELISA: In order to appreciate the degree of the sensitization of the animals to $\beta$-Lg and $\alpha$-La, we used immunoenzymatic technique (ELISA). This technique enables us to quantify the rate of the immunoglobulin of type $\operatorname{IgG}$ anti $\beta-\mathrm{Lg}$ and anti $\alpha$-La of the cow's milk.

IgG anti $\beta$-Lg and anti $\alpha$-La were assayed in serum sample by Enzyme-Linked Immunosorbent (ELISA). The procedure was as follow: The microtiter plates (Maxisorp; Nunk, Roskilde, Danemark) were coated with $100 \mu \mathrm{L} /$ well antigen ( $\beta$-Lg or $\alpha$-La) $\left(10 \mu \mathrm{g} \mathrm{mL}^{-1}\right)$ in phosphate-buffered saline, $10 \mathrm{mM} \mathrm{pH} 7.4$ and incubated for $48 \mathrm{~h}$ at $4^{\circ} \mathrm{C}$. The plate was then washed with PBS-T, containing PBS $10 \mathrm{Mm}, \mathrm{pH} 7.4$ and $0.05 \%$ Tween-20 (Sigma, P7949, USA). Residual free binding sites were blocked with $200 \mu \mathrm{L} /$ well of $2 \%$ gelatin of fish for $1 \mathrm{~h}$ at $37^{\circ} \mathrm{C}$. The plate was washed, filled with $100 \mu \mathrm{L} /$ well of diluted mice serum (from $1 / 10^{-2}-1 / 10^{-7}$ diluted in $1 \%$ gelatin of fish) (Sigma, G 7765, USA) on automated strip washer (ELx 50, Bio-Tek instruments $\mathrm{GmbH}$, Germany) and incubated for $2 \mathrm{~h}$ at $37^{\circ} \mathrm{C}$. After washing twice with PBS-Tween 20, the plate was incubated for $1 \mathrm{~h} 30$ at $37^{\circ} \mathrm{C}$ with $100 \mu \mathrm{L} /$ well of goats anti-mouse IgG Biotin (Sigma, B9904, France). After washing, $100 \mu \mathrm{L} /$ well of Extravidin peroxydase (Sigma-Aldrich E2886, France) was added. Incubation was carried out for $30 \mathrm{~min}$, at $37^{\circ} \mathrm{C}$. Then OPhenylenediamine Dihydrochloride (OPD) (Sigma, P1526-25G, USA) in a $50 \mathrm{mM}$ sodium citrate buffer, $\mathrm{pH} 5.1$, was used as a substrate. After incubation the plate at room temperature for $30 \mathrm{~min}, 50 \mu \mathrm{L}$ of sulphuric acid $(2 \mathrm{~N})$ was added to stop the enzymatic reaction. Between each incubation, the plates were washed with PBS containing $0.05 \%$ of tween 20. Absorbance values were read at $492 \mathrm{nM}$ on an automated plate reader $(\mathrm{EL} \times 800$, Bio-Tek instruments GmbH, Germany).

Cross-reactivity of dromedary whey proteins with IgG anti bovine $\beta$-Lg and anti bovine $\boldsymbol{\alpha}$-La: We checked for possible recognition of dromedary whey proteins by specific IgG directed against bovine $\beta$-Lg and bovine $\alpha$-La, by using immunoenzymatic technique as also described but with some modifications. The plates were incubated by antigens but this time with whey proteins of cow's and dromedary milk. The whey proteins of cow's milk are used as reference to compare them with the samples of dromedary milk.

Statistical analysis: Results were expressed as means \pm Standard Error (ES). All experiments were repeated six times. Obtained data were statistically analysed using student's test as programmed by STATISTICA version (5), 2006.

\section{RESULTS AND DISCUSSION}

Analyze of proteins of dromedary milk by electrophoresis (Fig. 1) reveals the existence of bands similar to bovine proteins (caseins, serum albumin bovine and $\alpha$-lactalbumin). However there is no one band corresponding to $\beta$-lactoglobulin. These results are in agreement with those of ${ }^{[11-14,16]}$.

However we detected the existence of an "unknown" peptide band migrating to the top of bovine $\beta$-lactoglobulin. This peptide was also detected by Farah $^{[11]}$ despite it is still unknown.

The chromatogram of whey dromedary featured one peak (indicated in Fig. 2 as I) corresponding to $\alpha$ lactalbumin (peak I), compared to the chromatogram of bovine proteins ( $\alpha$-lactalbumin and bovine serum albumin). There is no peak corresponding to $\beta$ lactoglobulin. The peak $I$ is also detected by Kappeler $^{[15]}$ showed a similitude of major proteins for camel milk with bovine milk except $\beta$-lactoglobulin which misses from dromedary milk. 
Am. J. Applied Sci., 6 (8): 1448-1452, 2009

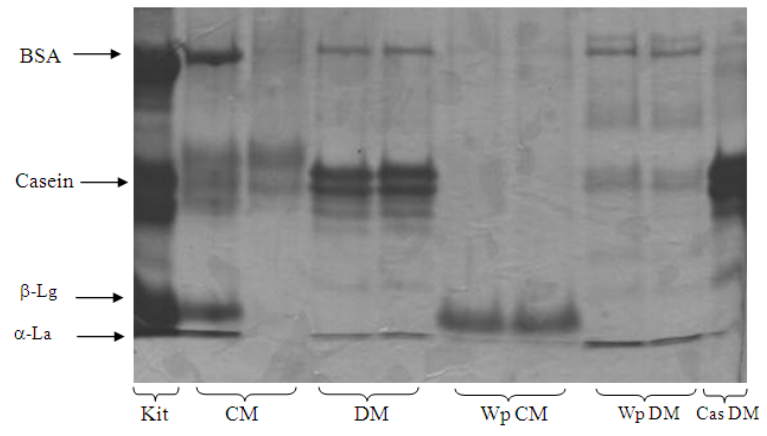

Fig. 1: Electrophoretic patterns of SDS-PAGE of dromedary and cow'smilk. Kit = Molecular Weight (MW) standards containing: Bovine serum albumin (MW 68,000 Da), casein (MW 24,000 Da), $\beta$-lactoglobulin $(\alpha-\mathrm{Lg}$, MW 18,000 Da) and $\alpha$-lactalbumin ( $\alpha$-La, MW 14,000 Da). CM = Cow's milk. $\mathrm{DM}=$ Dromedary milk. $\mathrm{Wp}=$ Whey protein. Cas $=$ Casein

After 35 days of sensitizing, which corresponds to the day of sacrifice, we detected in the serum of immunized mice a very high quantity of $\operatorname{IgG}$ antibovine $\beta-\mathrm{Lg}$ and anti bovine $\alpha-\mathrm{La}\left(1 / 10^{-6}\right)$ which is strongly significant $(\mathrm{p}<0.001)$ compared to the control group (Fig. 3). These results showed the strong power of the adjuvant used to cause an immunological response $^{[15]}$.

The cross-reactivity of dromedary whey proteins which was carried out to bring together these proteins with $\mathrm{IgG}$ anti bovine $\beta$-Lg and bovine $\alpha$-La showed that there was a very slight cross reaction between the whey proteins of the dromedary and $\mathrm{IgG}$ anti bovine $\beta$ - $\mathrm{Lg}$ (Fig. 4 and 5). The values obtained are significantly lower than those obtained with the whey proteins of the cow's milk. This non-recognition suggests the absence of $\beta$ - $\mathrm{Lg}$ to the dromedary milk ${ }^{[11-14]}$. These results are in accordance with those of ${ }^{[17]}$.

Indeed this researcher showed that the proteins of dromedary milk seem to be the only proteins which had not been recognized by serum antibodies of IgE type of children allergic to proteins in cow's milk. This can be explained by the fact that the cow and the dromedary are two species taxonomically distant. With regard to the cross-reactivity between whey proteins of dromedary and $\operatorname{IgG}$ anti bovine $\alpha-\mathrm{La}$, it has been noticed that there is no significant difference between the whey proteins of cow's and dromedary's milk.

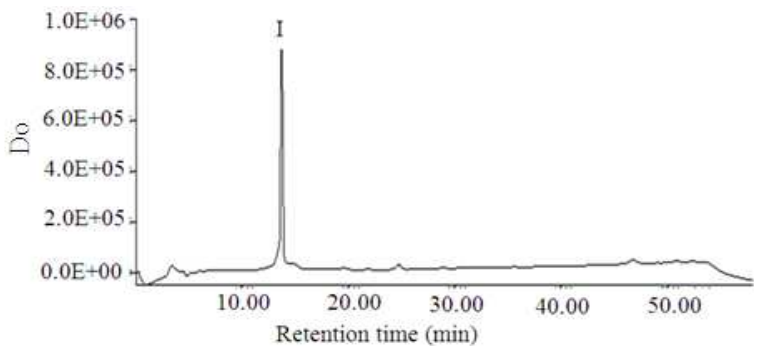

(a)

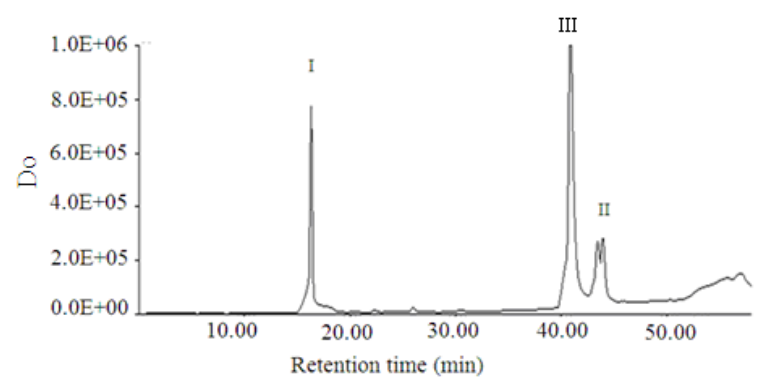

(b)

Fig. 2: Reversed-phase C18 RP-HPLC chromatogram of (a): Dromedary whey proteins, peak I correspond to $\alpha$-lactalbumin purified, (b): Bovine proteins, peak I, II and III correspond respectively to $\alpha$-lactalbumin, bovine serum albumin and $\beta$-lactoglobulin

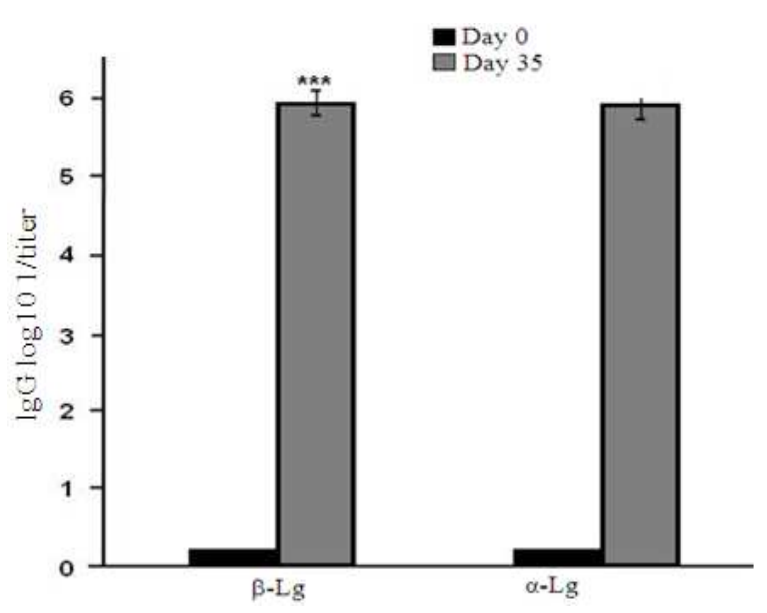

Fig. 3: Levels of $\operatorname{IgG}$ anti $\beta$ - $\mathrm{Lg}$ and anti $\alpha$-La for immunized mice with bovine $\beta-\operatorname{Lg}(n=12)$ and bovine $\alpha-\mathrm{La}(\mathrm{n}=12)$ compared to control $(\mathrm{n}=12)$ measured by Enzyme-Linked Immunosorbent Assay (ELISA) and expressed as $\log _{10}$ of $1 /$ titer. Results are expressed as mean \pm standard error of means (SE). $* * *: p<0.0001$ 


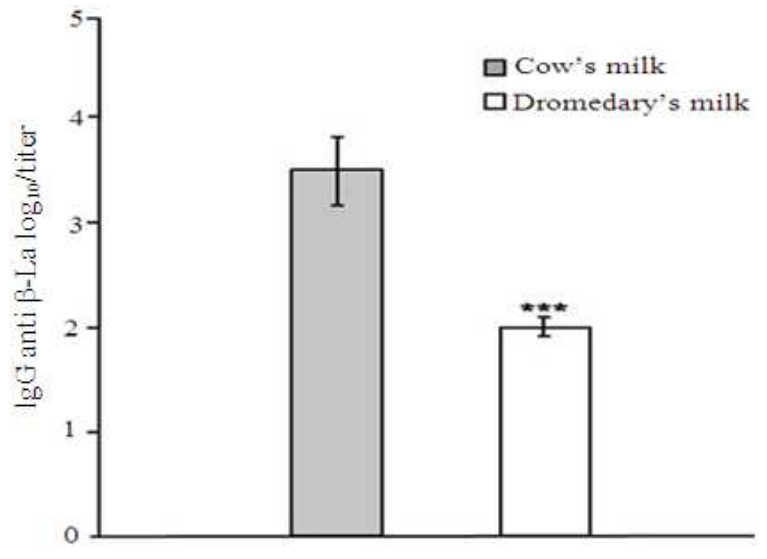

Fig. 4: Cross reactivity of dromedary and cow's whey proteins with $\operatorname{IgG}$ anti bovine $\beta$ - $\mathrm{Lg}$ measured by enzyme-linked immunosorbent assay (ELISA) and expressed as $\log _{10}$ of $1 /$ titer. Results are expressed as mean \pm Standard Error of means (SE) from independent measurements $(\mathrm{n}=6) . * * *: \mathrm{p}<0.0001$

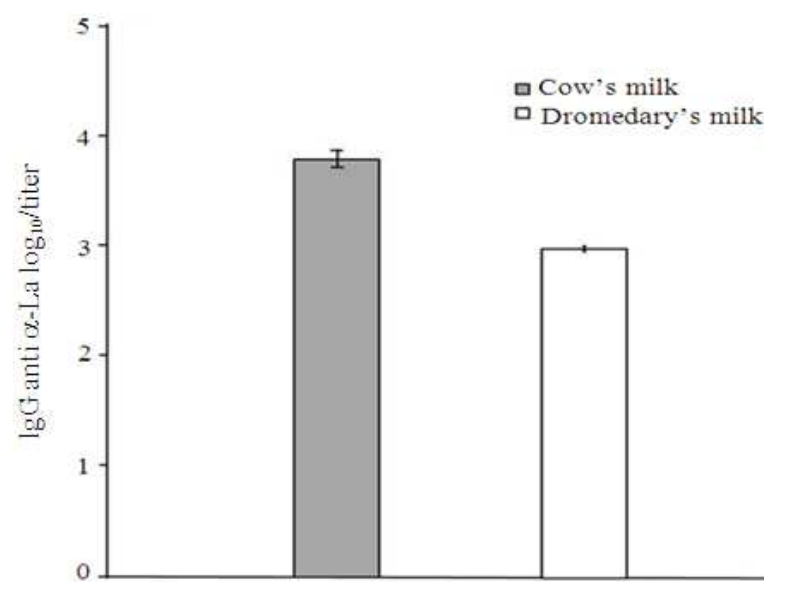

Fig. 5: Cross reactivity of dromedary and cow's whey proteins with IgG anti bovine $\alpha$-La measured by Enzyme-Linked Immunosorbent Assay (ELISA) and expressed as $\log _{10}$ of $1 /$ titer. Results are expressed as mean \pm Standard Error of means (SE) from independent measurements $(n=6)$

It showed that whey proteins of dromedary milk cross react with $\operatorname{IgG}$ anti bovine $\alpha$-La and it could be explained by the fact that these two proteins are similar in the composition of their structures and can contain some similar sequences. In addition to that and according to Restani et al. ${ }^{[17,18]}$ the cross reactions were observed between proteins of milk and meats, such as caseins and albumin, of different species like the cow, goat, ewe and mare and it was explained by the probable resemblance in the sequence of their proteins.

\section{CONCLUSION}

Heterogeneity of dromedary and cow seem not to be sufficient to avoid cross reactivity between both species' milk. The dromedary whey proteins have a sufficient antigenic potential to cross react with $\operatorname{IgG}$ anti bovine $\alpha$ $\mathrm{La}$ and can not bind $\operatorname{IgG}$ anti bovine $\beta$-Lg.

\section{ACKNOWLEDGEMENT}

This study was financially supported by the Agence Nationale Pour le Développement de la Recherche en Santé (ANDRS). Ms. Malika SACI is acknowledged for her corrections of the manuscript.

\section{REFERENCES}

1. Rancé, F. and E. Bidat, 2000 All the Food Allergies Do not Resembles Each other Food Allergy in the Child (Chapter 5). In: Medicine and Hygiene, Rancé, F. and E. Bidat (Eds.). Genève, pp: 210-221.

2. Spuergin, P., M. Walter, E. Schiltz, K. Deichmann, J. Forster and H. Mueller, 1997. Allergenicity of alpha-caseins from cow, sheep and goat. Allergy, 52: 293-298.

http://www.ncbi.nlm.nih.gov/pubmed/9140519

3. Infante Pina, D., R. Tormo Carnice and M. Conde Zandueta, 2003. Use of goat's milk in patients with cow's mikl allergy. An. Pediatr. (Barc), 59: 2: 138-142.

http://www.ncbi.nlm.nih.gov/pubmed/12882742

4. Pessler, F. and M. Nejat, 2004. Anaphylactic reaction to goat milk in cow's milk-allergic infant. Pediatr. Allerg. Immunol., 15: 183-185. DOI: 10.1046/j.1399-3038.2003.00087.x

5. Sampson, H.A., 1999. Food allergy. Part 1: Immunopathogenesis and clinical disorders. J. Allergy Clin. Immunol., 103: 717-728. http://www.ncbi.nlm.nih.gov/pubmed/10329801

6. Calvani, M. and C. Alessendri, 1998. Anaphylaxis to sheep's milk cheese in a child unaffected by cow's milk protein allergy. Eur. J. Pediatr., 157: 17-19.

http://www.ncbi.nlm.nih.gov/pubmed/9461357

7. Bellioni-Businco, B., R. Paganelli, P. Lucenti, P.G. Giam-Pietro, H. Perborn and L. Businco, 1999. Allergenicity of goat's milk in childrens with cow's milk allergy. J. Allerg. Clin. Immunol., 103: 1191-1194.

http://www.ncbi.nlm.nih.gov/pubmed/10359905 
8. Restani, P., B. Beretta, A. Fiocchi, C. Ballabio and C.L. Galli, 2002. Cross reactivity between mammalian proteins. Ann. Allergy Asthma Immunol., $\quad$ 89: 11-15. http://www.ncbi.nlm.nih.gov/pubmed/12487198

9. Ah-Leung, S., H. Bernard, E. Bidat, E. Paty, F. Rancé, P. Scheinmann and J.M. Wal, 2006. Allergy to goat and sheep milk without allergy to cow's milk. Allergy, 61: 358-365.

http://cat.inist.fr/?aModele $=$ afficheN\&cpsidt $=1814$ 9034

10. Laemelli, U.K., 1970. Cleavage of structural proteins during the assembly of the head of bacteriophage T4. Nature, 227: 680-685. http://www.ncbi.nlm.nih.gov/pubmed/5432063.

11. Farah, Z., E. Ebernard, P. Meyer, B. Rehberger, A. Thomet and P.U. Gallman, 2004. UHT processing of camel milk.

http://www.laitsain.com/files/Poster_Camel_2004_ D.pdf

12. Saidi, D., M. Kihal, A. Hammama, A. Chekroune, D.E. Henni and O. Kheroua, 2005. Characterization of Algerian raw camel's milk identification of dominant lactic bacteria and proteins analysis. J. Alg. Rég. Ar., 4: 01-09. http://www.crstra.dz/Publication/index.htm?Revue s.htm

13. Shabo, Y., R. Barzel, M. Margoulis and R. Yagil, 2005. Camel milk for food allergies in children. Isr. Med. Assoc. J., 7: 796-798. http://www.ncbi.nlm.nih.gov/pubmed/16382703
14. El-Hatmi, H., J.M. Girardet, J.L. Gaillard, M.H. Yahyaoui and H. Attia, 2007. Characterisation of whey proteins of camel (Camelus dromedarius) milk and colostrums. Small Rumi. Res., 2: 267-271. DOI: 10.1016/j.smallrumres.2006.04.001

15. Kappeler, S., 1998. Compositional and structural analysis of camel milk proteins with emphasis on protective proteins. Dissertation of ETH (Swiss Federal Institute of Technology) No. 12947 Zurich. http://www.sfiar.ch/documents/1999_research/kap p.htm

16. Adel-Patient, K., C. Créminon, H. Bernard, G. Clément and J.M. Chatel, 2000. Evaluation of high IgE responder mouse model of allergy to bovine $\beta$ lactoglobulin $(\beta-\mathrm{Lg})$ : Development of sandwich immunoassay for total and allergen-specific IgE, IgG1 and $\operatorname{IgG} 2 \mathrm{a}$ in $\beta-\mathrm{Lg}$ sensitized mice. J. Immunol. Methods. 235: 21-32. http://www.ncbi.nlm.nih.gov/pubmed/10675754

17. Restani, P., A. Gaiaschi, B. Beretta, G. Cavagni and C.L. Galli, 1999. Cross-reactivity between milk proteins from different animal species. Clin. Exp. Allergy, 29: 997-1004. http://www.ncbi.nlm.nih.gov/pubmed/10383602

18. Restani, P., B. Beretta, A. Fiocchi, C. Ballabio and C.L. Galli, 2002. Cross reactivity between mammalian proteins. Ann. Allergy Asthma Immunol., 89: 11-15.

http://www.ncbi.nlm.nih.gov/pubmed/12487198 